Discussion Paper No. 02-19

\title{
Factor Mobility, Government Debt and the Decline in Public Investment
}

Friedrich Heinemann

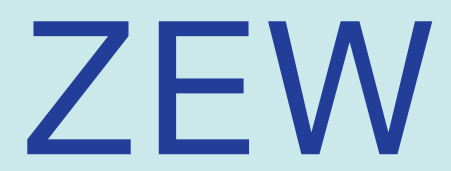

Zentrum für Europäische Wirtschaftsforschung GmbH

Centre for European

Economic Research 
Discussion Paper No. 02-19

\title{
Factor Mobility, Government Debt and the Decline in Public Investment
}

\author{
Friedrich Heinemann
}

Download this ZEW Discussion Paper from our ftp server:

ftp://ftp.zew.de/pub/zew-docs/dp/dp0219.pdf

Die Discussion Papers dienen einer möglichst schnellen Verbreitung von neueren Forschungsarbeiten des ZEW. Die Beiträge liegen in alleiniger Verantwortung der Autoren und stellen nicht notwendigerweise die Meinung des ZEW dar.

Discussion Papers are intended to make results of ZEW research promptly available to other economists in order to encourage discussion and suggestions for revisions. The authors are solely responsible for the contents which do not necessarily represent the opinion of the ZEW. 


\section{Non-technical Summary}

During the nineties, in many OECD countries a marked drop of government investment spending has occurred. The reasons for this reduction are not very well understood. While for some EU countries the consolidation pressure from the Maastricht criteria might add to the explanation, this explanation does not help in regard to countries for which EMU deficit limits are irrelevant. Furthermore, the decline seems to stand in contradiction to insights from the globalisation debate. The relative shift of public expenditures towards consumption spending is puzzling in times of increasing factor mobility. With companies becoming more footloose, one would expect government budgets to be restructured towards the needs of these mobile factors which should benefit public investment versus consumption. With this background, the paper tries to contribute to a better understanding of the economic and political forces driving public capital formation in industrial countries.

The theoretical framework is based on a model of budget optimisation: Fiscal decision makers choose a budget where marginal vote losses of raising revenues equal marginal vote gains from spending increases. This framework allows to derive a testable relationship for the determinants of public investment. Generally speaking, all developments that increase the marginal political benefits of public capital formation (the demand side) and that reduce the marginal political costs of financing it (the supply side) should increase investment. Among the factors that could thus have an impact on public investment are: return on investment, political discount factor, mobility of the tax base, political ideology, borrowing costs, sustainability of public debt and the existence of constitutional debt limits.

The econometric part of the paper tries to identify which of these factors are most relevant. For that purpose, country panels are estimated for 16 OECD countries for the period 1980-1999 with the level of investment being the dependent variable and appropriate proxies for the potential driving forces of investment as explanatory variables. Furthermore, it is controlled for the business cycle and the impact of the privatisation process in this period since this could otherwise bias the results.

The most robust results concern the level of hidden and open public debt $-\mathrm{a}$ high debt level is associated with a low level of public investment. Thus the decline of public investment in the nineties can be regarded as a consequence of fast growing debt mountains between the 70s and the $90 \mathrm{~s}$. This results clearly underlines the costs of public debt for future generations: In times of growing debt services it becomes increasingly difficult to mobilise government revenues for new investment projects.

Furthermore, mobility of factors adds to the explanation. Although investment might be a useful instrument to attract mobile factors (demand effect), its financing burden deters mobile factors (supply effect). According to these results, the supply effect dominates the demand effect. 
One further result concerns the impact of privatisation: this does not seem to have played any role in explaining the decline in investment. The control variable was insignificant. This is an uneasy insight: The excuse that the investment decline might be a statistical deception due to the privatisation process is not valid. In the European context it is interesting to stress that according to the econometric results the EMU deficit limits did not in a significant way add to the decline in investment. 


\title{
Factor Mobility, Government Debt and the Decline in Public Investment
}

\author{
Friedrich Heinemann \\ Zentrum für Europäische Wirtschaftsforschung (ZEW)
}

February 2002

\begin{abstract}
This paper tries to explain the declining level of public investment in OECD countries. The theoretical framework hints to the relevance of a number of demand and supply factors - ranging from the yield of public investment to institutions like the EU deficit limits. The econometric results indicate that the decline is largely due to two developments: First to the pile-up of public debt since the 70s which in the 90 s severely restricted ability to finance new investment. Second to the increasing mobility of factors that has added to the financing difficulties. In contrast to that neither the privatisation process nor EU deficit restrictions of the Maastricht Treaty can explain the decline.
\end{abstract}

JEL-Classification: H 50, H 63, H87

Keywords:

public investment, factor mobility, globalisation, public debt, OECD, EU

\section{Acknowledgment:}

The author gratefully acknowledges financial support by the German Science Foundation (DFG) within the research program „Governance in the European Union“.

L 7, 1

P.O. Box 103443

D-68034 Mannheim
Phone: $\quad 0621 / 1235-149$

Fax: $\quad 0621 / 1235-223$

E-mail: heinemann@zew.de 


\section{Introduction}

During the nineties in many OECD countries a marked drop of government investment spending has occurred. Figure 1 depicts public capital formation in relation to total budget and GDP for the big four EU countries, USA and Canada. The graphs indicate that falling investment-GDP-ratios are not a consequence of a shrinking size of government but rather result from a shift of government resources towards consumption.

Figure 1: Public investment

(solid line: relation to budget, dotted line: relation to GDP)

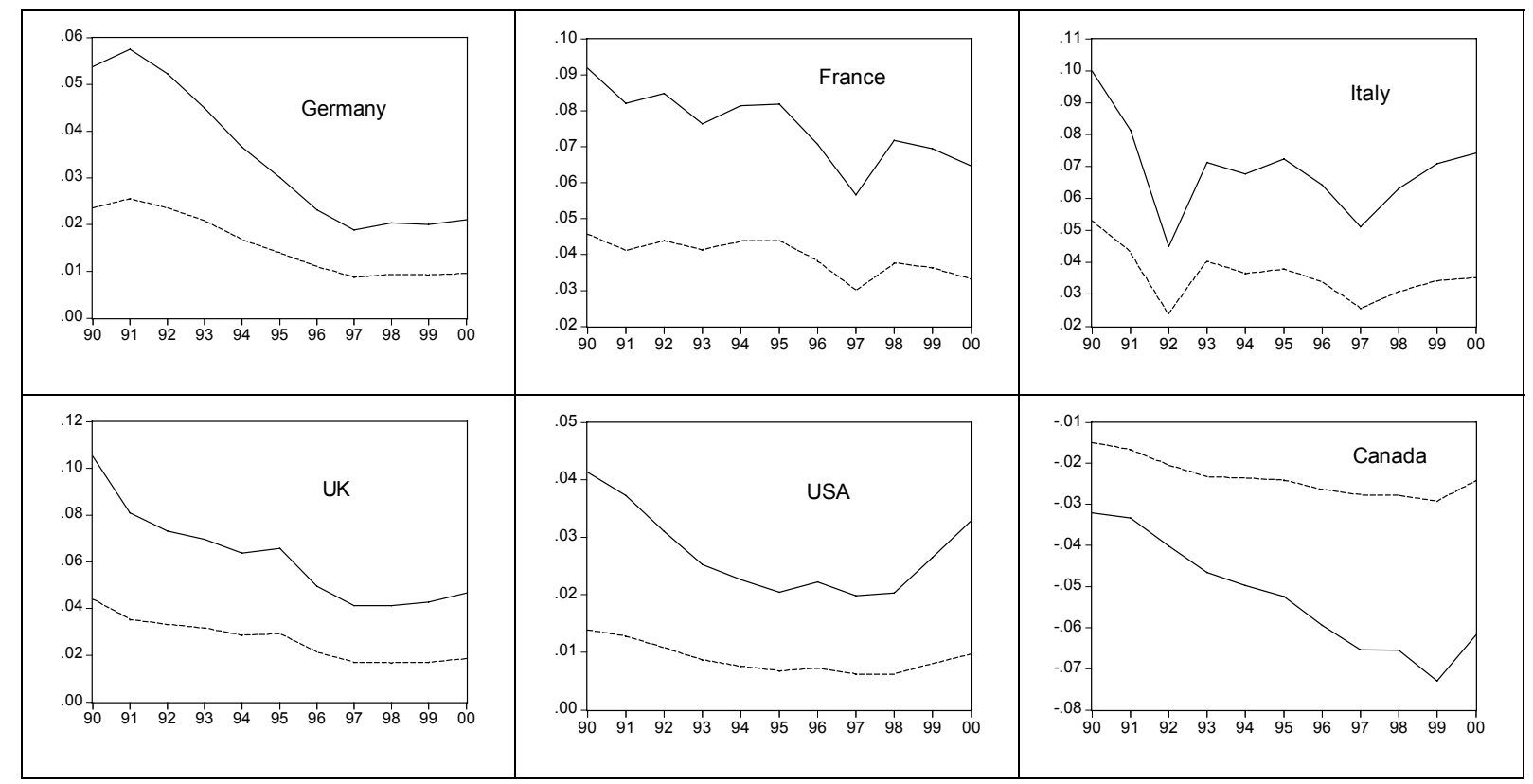

Source: OECD Fiscal Positions and Business Cycles database.

The reasons for this reduction are not very well understood. While for some EU countries the consolidation pressure from the Maastricht criteria might add to the explanation (BALASSONE/FRANCO, 2000), this explanation does not help in regard to countries for which EMU deficit limits are irrelevant. Furthermore, the decline seems to stand in contradiction to insights from the globalisation debate. The relative shift of public expenditures towards consumption spending is puzzling in times of increasing factor mobility. With companies becoming more footloose, one would expect government budgets to be restructured towards the needs of these mobile factors.

On the revenue side some developments can be interpreted in this way. In many countries the fiscal burden is shifted away from corporate taxes towards indirect 
taxes and social security contributions. ${ }^{1}$ On the expenditure side, however, the development stands in contrast to globalisation theory. Assuming that mobile agents like multinational firms appreciate public investment spending more than consumption spending one should expect an increase of public investment and not a decline. This should hold in particular for the nineties which were characterised by the abolition of many restrictions to capital flows and a boom of foreign direct investment.

With this background, the paper tries to contribute to a better understanding of the economic and political forces driving public capital formation in industrial countries. At the same time it tries to fill a gap in the empirical literature on the relationship between globalisation and budgetary policy. This empirical literature (surveyed in SchUlze/UrSPRUNG, 1999, and VAUBEL, 2000) so far has largely ignored investment spending. Only two studies are known to the author, where a relationship between globalisation indicators and public investment is tested "by the way" without paying particular interest to this expenditure variable and to the political-economic processes determining public investment. RODRIK (2000) who is mainly interested in the puzzle of a positive correlation between globalisation indicators and government consumption also includes cross section regressions for investment-GDP-ratios based on a large sample of more than a hundred countries. The analysis is based of data averages for two periods: 1985-1989 and 1990-1992. RODRIK finds regional dummies, a dummy for socialists in power (negative) and openness (share of trade in GDP, positive) to be the only significant explanatory variables for public investment. GARRETT (1998) executes panel estimations for 14 OECD countries between 1966 and 1990 for different expenditure categories, among them also investment spending. In this regression, the two globalisation indicators (trade and existence of restrictions imposed on international transactions as reported annually by the IMF) are not significant, only cyclical variables have a measurable impact on public investment.

These studies leave many questions unresolved. They end in the early nineties and thus cannot account for integration boosts like the completion of the EU internal market. Furthermore, important potential determinants of public investment are missing. Although Garrett suspects that privatisation programmes could be behind the decline of investment he does not test for this possibility. ${ }^{2}$ Furthermore it is questionable whether globalisation indicators like trade-GDP-ratios really measure the developments that are most relevant for public investment. Proxies for capital costs, the political-economic rate of time preference and liquidity contraints are

1 SChUlZE/URSPRUNG (1999) survey the empirical literature on tax competition. The evidence for some downward competition of corporate taxes is strong in studies based on (effective) tax rates. Revenue based studies come to contradicting remarks.

2 See SCHIPKE (2001) for the driving forces behind the privatisation tendencies. 
missing. This paper tries to address these shortcomings by the integration of appropriate variables.

In the following section 2 a framework is presented which allows to identify potential political and economic determinants of public capital formation together with a discussion of available variables. The section 3 presents the econometric analysis based on an OECD country panel. Section 4 concludes.

\section{Theoretical determinants and available proxies}

A basic insight of the political-economic theory on budget optimisation based on probabilistic voting (see for example HETTICH/WINER, 1997) is the following: For any expenditure item an optimising government under political competition will choose the level where marginal vote losses of raising revenues equals marginal vote gains from spending increases.

This basic concept is also helpful to derive a testable relationship for the determinants of public investment. Generally speaking, all developments that increase the marginal political benefits of public capital formation (the demand side) and that reduce the marginal political costs of financing it (the supply side) should increase investment. Table 1 and 2 summarise on that basis possible determinants for public investment and suggests employable indicators.

\section{Demand side:}

Among the factors that lead to an increasing appreciation of public investment among voters is its yield for the general economy. However, the relevance of future returns on investment for today's decision is affected by the political discount rate. The larger the discount rate the less interest is paid to the returns on public investment.

If enterprises for which public investment is an input factor are mobile this should also positively influence the political demand for public investment since these expenditure become a variable to attract foreign companies and thus to foster employment and growth. The same holds in the case of mobile households for which public investment has a direct positive impact on utility.

Furthermore, the ideology of governments concerning the role of the state in the economy and spending priorities can be regarded as a demand factor.

\section{Supply side:}

From supply side considerations all factors tend to decrease equilibrium investment that increase the costs of raising revenues. Real interest rates and debt sustainability should matter. If borrowing costs increase or the debt situation comes close to a debt 
crisis this negatively affects the power of any government to raise revenues. The same holds for binding institutional limits on deficit financing. Such limits exist in EU countries with the EMU convergence criteria and the subsequent Pact for Stability and Growth. Figure 1 above is suggestive in regard to these institutions' relevance: The European countries all show a marked drop of public investment in 1997. This year was the basis for EMU convergence tests in May 1998. It appears as if investment has been cut temporarily in the reference year in order to keep government deficits below the 3 per cent ceiling of the Maastricht Treaty.

In addition, the following factors should reduce the optimal level of investment from the supply side consideration: A low political discount rate since it leaves deficit financing less attractive and a high mobility of the tax base since this restricts the taxation power of a government.

Note that both the political discount rate and factor mobility thus have an impact on optimum public investment through both the demand and the supply side - with contradicting signs. Mobility of factors will only positively impact on public investment if the demand effect (public capital formation leaves a location more attractive) outweighs the supply effect (the financing needs drive out the mobile tax base). Similarly, a small discount rate will only foster investment if the demand effect (return on investment has a larger political impact) more than counterbalances the supply effect (the burden of the debt is taken more seriously).

Table 1: Factors relevant for marginal political benefits of public investment (demand side)

\begin{tabular}{|l|c|c|}
\hline factor & $\begin{array}{c}\text { expected sign of } \\
\text { investment impact }\end{array}$ & indicators \\
\hline return on investment & + & $\begin{array}{c}\text { per capita income, } \\
\text { population growth }\end{array}$ \\
\hline political discount rate & - & $\begin{array}{c}\text { indicators of political } \\
\text { stability }\end{array}$ \\
\hline $\begin{array}{l}\text { mobility of firms for } \\
\text { which investment is } \\
\text { input }\end{array}$ & + & globalisation indicators \\
\hline $\begin{array}{l}\text { elected governments } \\
\text { preference concerning } \\
\text { the role of government } \\
\text { and spending priorities }\end{array}$ & $\begin{array}{c}\text { (Rodrik, 2000: left } \\
\text { governments invest less) }\end{array}$ & $\begin{array}{c}\text { share of left parties' seats in } \\
\text { government coalition }\end{array}$ \\
\hline
\end{tabular}


Table 2: Factors relevant for the marginal political costs of public investment (supply side)

\begin{tabular}{|l|c|c|}
\hline factor & $\begin{array}{c}\text { expected sign } \\
\text { of investment } \\
\text { impact }\end{array}$ & indicators \\
\hline borrowing costs & - & $\begin{array}{c}\text { real interest rate relevant for public } \\
\text { borrowing }\end{array}$ \\
\hline risk of debt crisis & - & $\begin{array}{c}\text { sustainability indicators like debt- } \\
\text { GDP-level or proxies for hidden debt } \\
\text { (age structure) }\end{array}$ \\
\hline $\begin{array}{l}\text { political costs of deficits } \\
\text { due to institutional } \\
\text { constraints }\end{array}$ & - & $\begin{array}{c}\text { Maastricht convergence criteria } \\
\text { variable }\end{array}$ \\
\hline political discount rate & + & Pact for Stability and Growth variable \\
\hline mobility of tax base & - & indicators of political instability \\
\hline
\end{tabular}

Tables 1 and 2 also include in the third column indicators that are used in this study as proxies for each determinant of public investment (for sources see table in appendix):

- The measurement of growth effects of public capital formulation is a demanding task (see BALASSONE/FRANCO, 2000, for a short survey on that literature). Here, a pragmatic way is chosen and some easily available structural variables are used as proxies for the return to public capital formation: population growth measured by the fertility rate - and per capita income.

- The number of elections or cabinet reshuffles (EOC) in the last three years is used as an indicator of political stability which stands for the political discount rate of a country.

- Political preferences can be measured in terms of political orientation of the government. The specific variable employed is the share of left parties' seats in the governing coalition ( $L I G)$.

- Real interest rates are an obvious specification for borrowing costs. These are calculated ex post, i.e. as the difference between long term government bond yields and the actual inflation rate.

- The debt-GDP-level is a rough but easily accessible sustainability indicator. It has, however the problem, to be solely based on the explicit part of the public debt. In order to take also account of the hidden part, the share of population below the age of 14 is added to the explanatory variables - a low share indicating a large hidden (demographically caused) public debt. 
- As suggested by the time series plot, a 1997 dummy for first wave EMU countries can serve as a proxy for the effects of the Maastricht convergence criteria. 1997 was the budgetary period that decided over EMU membership in 11 countries. A temporary cutback of public investment might have been used to fulfil the $3 \%$ deficit/GDP condition. ${ }^{3}$

Turning now to the variables measuring mobility of factors in an increasingly globalised environment there is the problem of choice. Indicators measuring factor mobility can be constructed on very different bases. Concepts can be direct and then be based on the existence of obstacles to cross-border movements and transactions. Or they can be price related and then look for deviations from the law of one price. Quantity-related concepts focus on the size of cross-border transactions. It is hard to say which of all available indicators really measure the kind of mobility that is most relevant in the context of public investment optimisation. Therefore, a bundle of indicators is used in this study, the choice also dictated by the difficulties to collect sufficient time series cross section data for a sample of industrial countries. The globalisation variables used are the following:

Openness measured as (exports + imports)/GDP,

the stock (end of year) of inward and outward portfolio investment, bank assets and $F D I$ - all relative to GDP.

Apart from that for each country and year the number of restrictions is counted out of four types of restrictions reported by the IMF in its Exchange Arrangements and Exchange Restrictions reports.

- A count variable - years since the liberalisation of the capital account - is the final globalisation variable. The idea of this variable is that mobility is also a function of time after a liberalisation has occured.

Two further groups of variables have to be added to the analysis.

- First cyclical variables in order to control for an impact of the business cycle. Here the gap between potential and actual GDP and the unemployment rate is used.

- Second a proxy for privatisation. In theory, privatisation of publicly owned enterprises should not influence the level of public investment. According to the rules of national accounting these units and their investment are ascribed to the enterprise sector - whether the owner is the state or a private agent. However, in the context of privatisation during the nineties reclassifications e.g. of public utilities from general government to the private sector have occurred (BALASSONE/FranCO, 2000). Thus, the measured decline of public investment might partially be a statistical artefact due to privatisation. In order to take care

3 The dummy is defined to be 0 in 1997 for non-EU countries and for Denmark, Sweden and the United Kingdom where EMU membership was in that time no political objective. 
for this possibility, a proxy for public property is used: property income received by the government. A 3-year-moving-average of this time series is calculated in order to limit the cyclical pattern likely to characterise this series.

The table in the appendix informs about all data sources and summarises the specifications employed in the regressions.

\section{The econometric evidence}

In the following panel estimations are performed for up to 16 OECD countries. ${ }^{4}$ Estimations are based on the period 1980-1999. A dynamic specification (the lagged dependent variable is among the explanatory variables) is chosen, estimation technique is OLS with White heteroscedasticity-consistent covariances. There are two specifications of the dependent variable: public investment relative to GDP and relative to total government expenditures - the latter being more meaningful in times of a changing size of the state.

Columns (1) and (3) of Table 3 show the results of a specification including all those variables suggested in the preceding part. Apart form the lagged endogenous only the debt related variables and globalisation variables turn out to reach at least a 10 per cent level of significance. The significant debt variables have the expected sign: A larger debt tends to dampen investment. The mobility related variables suggest the dominance of the supply dimension in the optimisation on public investment: A high mobility measured as stocks of foreign bank assets and liabilities or as years since capital account liberalisation dampens investment. The LIG variable is in both specifications near the 10 per cent level: the sign is in line with the finding of RODRIK (2000) that left governments tend to invest less.

The next step - the regressions in columns (2) and (4) of Table 3 - are the result of eliminating those variables being far from significance. The results do not change very much apart from the finding that the modest significance of the left parties variable is not robust.

The switching significance between the variables indicating open and hidden public debt points towards a multicollinearity problem. The same could be the case with respect to the globalisation variables and their lacking significance in the column (4) specification. In order to cope with this problem there is a final estimation specification based on a preceding calculation of principle components. Both for the two debt variables and for the three mobility variables (bank assets/liabilities, number of restrictions, years since liberalisation) the first principle component is

4 Included are: Austria, Belgium, Canada, Denmark, Finland, France, Germany, Italy, Japan, Netherlands, Norway, Portugal, Spain, Sweden, United Kingdom and USA. Lacking data lead to the exclusion of Canada, Japan and Norway in the full specification (table 3, columns 1 and $3)$. 
calculated and then included as an explanatory variable in a panel regression. Table 4 reports the results. The debt variables are indeed jointly highly significant, the same does not hold for the mobility variables. Again the importance of Rodrik's left parties variable is not supported.

\section{Conclusion}

From theoretical considerations a whole range of variables could be important for the decision on public investment and therefore be able to explain its decline in recent years. The empirical evidence of this study only supports the importance of two variable groups: the debt and mobility related indicators.

The most robust results concern the level of hidden and open public debt - a high debt level is associated with a low level of public investment. Thus the decline of public investment in the nineties can be regarded as a consequence of fast growing debt mountains between the 70s and the 90s. This results clearly underlines the costs of public debt for future generations: In times of growing debt services it becomes increasingly difficult to mobilise government revenues for new investment projects.

Furthermore, mobility of factors adds to the explanation. Although investment might be a useful instrument to attract mobile factors (demand effect), its financing burden deters mobile factors (supply effect). According to these results, the supply effect dominates the demand effect.

Rodrik's finding about left governments being associated with lower investment levels does not survive in this richer specification. One further result concerns the impact of privatisation: this does not seem to have played any role in explaining the decline in investment. The control variable was insignificant. This is an uneasy insight: The excuse that the investment decline might be a statistical artefact due to the privatisation process is not valid. In the European context it is interesting to stress that the EMU deficit limits did not in a significant way add to the decline in investment. 
Table 3: Panel regression, fixed effects, OLS with White heterosecedasticitycorrection - probability in brackets - bold coefficients with at least $10 \%$ significance

\begin{tabular}{|c|c|c|c|c|}
\hline & (1) & (2) & (3) & (4) \\
\hline $\begin{array}{l}\text { Dependent } \\
\text { variable: }\end{array}$ & \multirow[t]{2}{*}{$\begin{array}{l}\text { investment/ } \\
\text { GDP }\end{array}$} & \multirow[t]{2}{*}{$\begin{array}{l}\text { investment/ } \\
\text { GDP }\end{array}$} & \multirow[t]{2}{*}{$\begin{array}{l}\text { investment/ } \\
\text { total public } \\
\text { expenditure }\end{array}$} & \multirow[t]{2}{*}{$\begin{array}{l}\text { investment/ } \\
\text { total public } \\
\text { expenditure }\end{array}$} \\
\hline $\begin{array}{l}\text { Explanatory } \\
\text { variables: }\end{array}$ & & & & \\
\hline dependent $(-1)$ & $0.487(0.00)$ & $0.631(0.00)$ & $0.448(0.00)$ & $0.644(0.00)$ \\
\hline income p. capita & $-0.000(0.91)$ & - & $-0.000(0.93)$ & - \\
\hline fertility rate & $0.003(0.47)$ & - & $0.009(0.27)$ & - \\
\hline$E O C$ & $-0.000(0.47)$ & - & $-0.001(0.13)$ & - \\
\hline$L I G$ & $-0.002(0.13)$ & $-0.001(0.50)$ & $-0.005(0.13)$ & $-0.002(0.43)$ \\
\hline real interest rate & $-0.016(0.66)$ & - & $-0.047(0.49)$ & - \\
\hline debt-GDP & $-0.0001(0.26)$ & $-0.0002(0.00)$ & $-0.0001(0.41)$ & $-0.0004(0.00)$ \\
\hline pop. share $<14$ & $0.001(0.26)$ & $-0.000(0.32)$ & $0.003(0.02)$ & $-0.000(0.86)$ \\
\hline $\begin{array}{l}\text { EMU } 1997 \\
\text { dummy }\end{array}$ & $-0.001(0.35)$ & - & $-0.002(0.45)$ & - \\
\hline output gap & $0.000(0.54)$ & - & $0.001(0.24)$ & - \\
\hline $\begin{array}{l}\text { unemployment } \\
\text { rate }\end{array}$ & $0.000(0.57$ & - & $0.000(0.81)$ & - \\
\hline property income & $-0.103(0.38)$ & - & $-0.268(0.26)$ & - \\
\hline openness & $-0.003(0.71)$ & - & $0.000(0.99)$ & - \\
\hline $\begin{array}{l}\text { portfolio } \\
\text { investment }\end{array}$ & $-0.001(0.83)$ & - & $0.000(0.97)$ & - \\
\hline $\begin{array}{l}\text { bank } \\
\text { assets/liabilities }\end{array}$ & $-0.006(0.10)$ & $-0.005(0.04)$ & $-0.013(0.09)$ & $-0.005(0.25)$ \\
\hline$F D I$ & $0.007(0.31)$ & - & $0.014(0.34)$ & - \\
\hline nb. of restrictions & $-0.001(0.25)$ & $-0.0003(0.61)$ & $-0.004(0.09)$ & $-0.001(0.40)$ \\
\hline $\begin{array}{l}\text { years since } \\
\text { liberal. }\end{array}$ & $-0.001(0.01)$ & $-0.000(0.75)$ & $-0.001(0.00)$ & $0.000(0.76)$ \\
\hline adj. R2 & 0.91 & 0.95 & 0.93 & 0.97 \\
\hline $\begin{array}{l}\text { number of } \\
\text { countries/ } \\
\text { observations }\end{array}$ & $13 / 175$ & $16 / 239$ & $13 / 175$ & $16 / 239$ \\
\hline sample & 1980-1998 & 1980-1999 & 1980-1998 & 1980-1999 \\
\hline
\end{tabular}


Tabel 4: Panel regression, fixed effects, OLS with White heterosecedasticitycorrection - probability in brackets - bold coefficients with at least $10 \%$ significance

\begin{tabular}{|c|c|c|}
\hline & (1) & (2) \\
\hline Dependent variable: & investment/GDP & $\begin{array}{c}\text { investment/total public } \\
\text { expenditure }\end{array}$ \\
\hline \multicolumn{3}{|l|}{ Explanatory variables: } \\
\hline dependent (-1) & $0.651(0.00)$ & $0.649(0.00)$ \\
\hline$L I G$ & $0.0009(0.45)$ & $-0.002(0.39)$ \\
\hline $\begin{array}{l}\text { principle component debt } \\
\text { variables }\end{array}$ & $-0.0001(0.00)$ & $-0.0004(0.00)$ \\
\hline $\begin{array}{l}\text { principle component } \\
\text { mobility variables }\end{array}$ & $-0.0000(0.73)$ & $-0.0000(0.83)$ \\
\hline adj. $R 2$ & 0.951 & 0.97 \\
\hline $\begin{array}{l}\text { number of countries/ } \\
\text { observations }\end{array}$ & $16 / 237$ & $16 / 237$ \\
\hline sample & 1980-1999 & 1980-1999 \\
\hline
\end{tabular}

\section{References}

Balassone, Fabrizio And Danielle Franco (2000): Public Investment, the Stability Pact and the "Golden Rule", Fiscal Studies, 21 (2), 207-229.

Garret, Geoffrey (1998): Partisan Politics in the Global Economy, Cambridge University Press, Cambridge.

Heinemann, Friedrich AND Viktor Winschel (2001): Public Deficits and Borrowing Costs: The Missing Half of Market Discipline, ZEW Discussion Paper, No. 01-16, Mannheim.

Hettich, Walter and Stanley Winer (1997), The Political Economy of Taxation, in: Dennis C. Mueller (ed.), Perspectives on Public Choice, Cambridge University Press, 481-505.

Lane, Jan-Erik, McKay, David and Kenneth Newton (1997): Political Data Handbook OECD Countries, New York.

RODRIK, DANI (1998): Why Do More Open Economies Have Bigger Governments? Journal of Political Economy, 106 (5), 997-1032.

SchipKe, Alfred (2001): Why Do Governments Divest? The Macroeconomics of Privatization, Springer-Verlag, Berlin Heidelberg.

SCHUlze, GÜNTHER G. AND HeINRICH W. URSPRUNG (1999): Globalisation of the Economy and the Nation State, in: The World Economy, 22 (3), 295-352. 


\section{Appendix: Variable definitions and sources}

\begin{tabular}{|c|c|c|}
\hline Variable name & Specification employed in regression & Source \\
\hline public investment & & OECD FPBC \\
\hline$G D P$ & & OECD FPBC \\
\hline fertility rate & & Eurostat \\
\hline $\begin{array}{l}\text { income per capita (in } \\
\text { PPS) }\end{array}$ & & Eurostat \\
\hline $\begin{array}{l}\text { EOC: } \text { elections or } \\
\text { cabinet reshuffles }\end{array}$ & 3 year moving sum & $\begin{array}{l}\text { Keesing's Record of World } \\
\text { Events, Lane/McKay/Newton } \\
\text { (1997): Political data handbook } \\
\text { OECD, Archiv der Gegenwart }\end{array}$ \\
\hline $\begin{array}{l}\text { LIG: share of left } \\
\text { parties' seats in } \\
\text { governing coalition } \\
\end{array}$ & & Archiv der Gegenwart \\
\hline real interest rates & $\begin{array}{l}\text { long term government bond yield - CPI } \\
\text { inflation }\end{array}$ & $\begin{array}{l}\text { bond yield from IMF IFS, CPI } \\
\text { inflation from OECD FPBC }\end{array}$ \\
\hline debt-GDP-level & & OECD FPBC \\
\hline $\begin{array}{l}\text { B14: share of population } \\
\text { below age of } 14\end{array}$ & & Eurostat \\
\hline $\begin{array}{l}\text { 1997EMU qualification } \\
\text { period dummy }\end{array}$ & $\begin{array}{l}1 \text { in } 1997 \text { for first wave EMU } \\
\text { countries, } 0 \text { otherwise }\end{array}$ & \\
\hline openness & (imports+exporte)/GDP & IMF IFS \\
\hline $\begin{array}{l}\text { FDI: Foreign direct } \\
\text { investment }\end{array}$ & $\begin{array}{l}\text { (sum of stocks of inward and outward } \\
\text { FDI)/GDP }\end{array}$ & IMF IFS \\
\hline $\begin{array}{l}\text { Portfolio: International } \\
\text { portfolio investment }\end{array}$ & $\begin{array}{l}\text { (sum of stocks of international portfolio } \\
\text { investment assets and liabilities)/GDP }\end{array}$ & IMF IFS \\
\hline $\begin{array}{l}\text { Bank: Bank foreign } \\
\text { assets and liabilities }\end{array}$ & $\begin{array}{l}\text { (sum of stocks of bank foreign assets } \\
\text { and liabilities)/GDP }\end{array}$ & IMF IFS \\
\hline Number of restrictions & $\begin{array}{l}\text { counts dummies for the existence of } \\
\text { four restrictions (yes }=1, \text { no }=0 \text { ): } \\
\text { 1. multiple exchange rates } \\
\text { 2. restrictions to capital account } \\
\text { transactions } \\
\text { 3. restrictions to current account } \\
\text { transactions } \\
\text { 4. obligation to surrender export } \\
\text { proceeds }\end{array}$ & IMF EAER \\
\hline Years since liberalisation & $\begin{array}{l}\text { Years since restrictions to capital } \\
\text { account transactions have been } \\
\text { abolished }\end{array}$ & IMF EAER \\
\hline Output gap & & OECD FPBC \\
\hline Unemployment rate & & OECD FPBC \\
\hline $\begin{array}{l}\text { Property income received } \\
\text { by the government }\end{array}$ & $\begin{array}{l}3 \text { year moving average of property } \\
\text { income/GDP }\end{array}$ & OECD FPBC \\
\hline
\end{tabular}

IMF IFS: International Financial Statistics; IMF EAER: Exchange Arrangements and Exchange Restrictions; OECD FPBC: Fiscal Positions and Business Cycles database. 